\title{
Review \\ Internet of Nonthermal Food Processing Technologies (IoNTP): Food Industry 4.0 and Sustainability
}

\author{
Anet Režek Jambrak ${ }^{1, *(\mathbb{D}}$, Marinela Nutrizio ${ }^{1}$, Ilija Djekić ${ }^{2}\left(\mathbb{D}\right.$, Sanda Pleslić $^{3}$ and Farid Chemat ${ }^{4}(\mathbb{D}$ \\ 1 Faculty of Food Technology and Biotechnology, University of Zagreb, 10000 Zagreb, Croatia; \\ marinela.nutrizio@pbf.unizg.hr \\ 2 Faculty of Agriculture, University of Belgrade, 11080 Zemun, Serbia; idjekic@agrif.bg.ac.rs \\ 3 Faculty of Electrical Engineering and Computing, University of Zagreb, Unska 3, 10000 Zagreb, Croatia; \\ sanda.pleslic@fer.hr \\ 4 Green Extraction Team, INRAE, Avignon University, 84029 Avignon, France; farid.chemat@univ-avignon.fr \\ * Correspondence: anet.rezek.jambrak@pbf.unizg.hr; Tel.: +385-14-605-287
}

check for updates

Citation: Režek Jambrak, A.; Nutrizio, M.; Djekić, I.; Pleslić, S.; Chemat, F. Internet of Nonthermal Food Processing Technologies (IoNTP): Food Industry 4.0 and Sustainability. Appl. Sci. 2021, 11, 686. https://doi.org/ 10.3390/app11020686

Academic Editor: Suyong Lee Received: 18 December 2020 Accepted: 8 January 2021 Published: 12 January 2021

Publisher's Note: MDPI stays neutral with regard to jurisdictional clai$\mathrm{ms}$ in published maps and institutional affiliations.

Copyright: $(2021$ by the authors. Licensee MDPI, Basel, Switzerland. This article is an open access article distributed under the terms and conditions of the Creative Commons Attribution (CC BY) license (https:// creativecommons.org/licenses/by/ $4.0 /)$.

\begin{abstract}
With the introduction of Industry 4.0, and smart factories accordingly, there are new opportunities to implement elements of industry 4.0 in nonthermal processing. Moreover, with application of Internet of things (IoT), smart control of the process, big data optimization, as well as sustainable production and monitoring, there is a new era of Internet of nonthermal food processing technologies (IoNTP). Nonthermal technologies include high power ultrasound, pulsed electric fields, high voltage electrical discharge, high pressure processing, UV-LED, pulsed light, e-beam, and advanced thermal food processing techniques include microwave processing, ohmic heating and high-pressure homogenization. The aim of this review was to bring in front necessity to evaluate possibilities of implementing smart sensors, artificial intelligence (AI), big data, additive technologies with nonthermal technologies, with the possibility to create smart factories together with strong emphasis on sustainability. This paper brings an overview on digitalization, IoT, additive technologies (3D printing), cloud data storage and smart sensors including two SWOT analysis associated with IoNTPs and sustainability. It is of high importance to perform life cycle assessment (LCA), to quantify (En)—environmental dimension; (So)—social dimension and (Ec)—economic dimension. SWOT analysis showed: potential for energy saving during food processing; optimized overall environmental performance; lower manufacturing cost; development of eco-friendly products; higher level of health and safety during food processing and better work condition for workers. Nonthermal and advanced thermal technologies can be applied also as sustainable techniques working in line with the sustainable development goals (SDGs) and Agenda 2030 issued by United Nations (UN).
\end{abstract}

Keywords: nonthermal food processing technologies; Food Industry 4.0; sustainability; zero emission; sustainable development goals; SWOT analysis

\section{Introduction}

Nonthermal processing (NTP) has been investigated for food applications for the purpose of food product stabilization and extraction, as alternative preservation processes to conventional application of thermal treatments, pre-treatments (before freezing, drying) in wastewater treatments and in different applications. There are electrotechnologies (cold plasma processing, pulsed electric fields-PEFs, pulsed light-PL, e-beam processing); pressure-based technologies like high pressure processing-HPP (cold preservationPascalization), high pressure homogenization and mechanical technologies (high power ultrasound-US, hydrodynamic cavitation). All of them deliver minimally processed food with same or improved quality attributes compared to thermal technologies. PEFs have been used in the treatment of industrial wastewater, allowing for significant recoveries and wastage reduction. Each technology has its advantages and disadvantages but all of them 
can be considered as promising for the present and future development of sustainable food applications. Scale-up principle of each technology is not the same, and progress made on the research and the results obtained for their industrial implementation differ from one technology to another. There are very few research papers that are dealing with comparison of sustainable parameters of nonthermal technologies, making a direct comparison with NTPs difficult [1-5].

The main inefficiencies within the food processing sector are food losses-wastes (by-products). Food processing technologies can contribute to reducing such inefficiencies by application of smart sensors for monitoring quality control over the entire supply chain. Waste management and control of machines, as well as interconnection in the processing plant, can be overcome by generating big data to optimize the system. With the introduction of Industry 4.0, smart factories, there are new opportunities to implement elements of industry 4.0 in nonthermal processing. Moreover, with application of Internet of things (IoT), smart control of the process, big data optimization, as well as sustainable production and monitoring, we have a new era of Internet of nonthermal food processing technologies (IoNTP): Food Industry 4.0 and sustainability.

Researchers and topics on nonthermal processing are mainly in lab-scale and proper scale up have been made for HPP and PEFs. There are many advantages where those technologies have proven to be more efficient compared to thermal one in terms of preservation [3]. Each technology has its advantages and disadvantages and there is no single one as appropriate for general use and for general purpose. The application of NTP technologies should be focused on specific and target usage with assuring preservation (food safety), food quality monitoring and total quality assessment with lowest energy and economic resources and least impact to the environment and to the society in general. Waste, energy, economy, and environment are major pillar that needs to be managed in terms of Agenda 2030 and Sustainable Development Goals (SDGs). Energy conservation is vital for the sustainable development of the food industry. Nonthermal technologies can be implemented in food industry in terms of reduced energy consumption, reducing energy costs and help to the society in general by reducing the use of energy resources and the emission of many air pollutants such as $\mathrm{CO}_{2}$. In food processing industry it has become significant to improve the energy efficiency and replace the existing energy-intensive unit operations with new energy-efficient processes [6]. Industry 4.0 also refers to smart factories that enables to address issues such as food safety, security, control, energy consumption, demand predictions of food manufacturing.

The aim of this review was to bring in front necessity to evaluate possibilities of implementing smart sensors, artificial intelligence (AI), big data, additive technologies with nonthermal technologies, with the possibility to create smart factories together with strong emphasis on sustainability. As a result of this part of the review, a SWOT matrix of novel food processing techniques has been created. Upon analysis of the sustainability perspective of nonthermal food processing associated with Food industry 4.0, second SWOT matrix has been developed. The three pillars of sustainability refer to environmental, economic and social impacts of nonthermal technologies (i.e., energy balances, life cycle assessment (LCA), waste production/reduction, cost of production, impact to society) as well to set novel approach to introduce nonthermal technologies as smart systems in food industries.

\section{Literature Review}

Literature review concerning sustainability of NTPs has been performed by analyzing manuscripts refer in scientific databases, mainly Web of Science, ScienceDirect and Google Scholar, revealing articles (research papers and reviews), targeting environmental/social impacts of NTPs and their relation with Industry 4.0 technologies, LCA studies focused on a specific food NTPs, and/or analysis of specific environmental impacts associated with food NTPs such as energy, water, climate change). The selection criterion was that food related NTP articles cover any environmental/sustainability dimension within the Industry 4.0 perspective. However, when keywords related to Food industry 4.0, sustainability and 
non-thermal food processing technologies were added to searching engines, two types of manuscripts were found: (i) papers connecting NTP and Industry 4.0, and (ii) manuscripts covering NTPs and sustainability. All three have not been in focus by author and this was identified as a research gap by the authors of this manuscript.

As a result of the literature review, two SWOT (Strength, weaknesses, opportunities, threats) analyses have been performed. First in relation to novel food processing techniques and second associating Food Industry 4.0 and sustainability dimensions. In both cases, scholars from University of Zagreb-Faculty of Food Technology and Biotechnology and University of Belgrade-Faculty of Agriculture with expertise in nonthermal food technologies and food sustainability created these SWOT matrices, using a Delphi method to stimulate and synthesize the opinions of these experts. Delphi method is often used to elicit experts' knowledge and achieve consensus [7].

\section{Principles of Industry 4.0}

\subsection{Food Industry 4.0: Principles}

Food Industry is constantly improving their processing and production with caution in environmental impact. There are many areas where there is a need for more improvements. The idea is driven by society, nature via climate change, profit, management where smart decisions are needed. There is view from different interdisciplinary and interprofessional leaders and professionals, where different aspects need to be considered. Industry 4.0 is a way to improve production processes, to increase the productivity, to reflect individual demands and short-term management wishes. The way of thinking together with Lean and Green management, is helping to reduce lead time and time to market [8]. Smart solutions of Industry 4.0 help to reduce product development time ad-hoc networking within cyber-physical systems (CPS). Moreover, it helps transparency in real time, to make faster and more flexible decision making, to archive global optimization in development and production [9]. Well known 1st, 2nd and 3rd industrial revolution enabled the transition from manual to mechanical production. Industry 4.0 is the fourth industrial revolution applying the principles of CPS, internet-oriented technologies and smart systems with enhanced human-machine interaction systems. This enables communication between every segment of the system in the value stream and leads to internet-enabled mass customization in manufacturing [10]. The term was first coined in 2011 at the Hanover Fair in Germany.

There are constant requirements regarding safety, nutritive composition, food fraud, and recently sustainability requirements. Thermal processing in food industry is most used way of preserving foods. In the last 15 years, many research of nonthermal food processing and scale-up on industrial level has been done. Nonthermal food processing includes electrotechnologies like cold plasma processing, PEFs, PL and e-beam processing. There are also pressure-based technologies like HPP (cold preservation-Pascalization), high pressure homogenization and mechanical technologies (high power US, hydrodynamic cavitation). Nonthermal technologies in connection with elements of Industry 4.0 and sustainability dimensions are presented in Figure 1. When discussing sustainability there can be improvements of already existing thermal technologies, in terms of lower energy consumption, lower emission of $\mathrm{CO}_{2}$, lower impact to the environments with waste reduction and its recycling (zero waste processing).

The improvements of advanced thermal and nonthermal technologies, in terms of elements of Industry 4.0 should go in line with Agenda 2030 (United Nations, UN). There are many obstacles and interdisciplinary approach is needed to overcome those obstacles [11]. Technologies such as 5G, IoT, remote sensing, big data analytics, AI, machine learning and blockchain can be connected in development of synergy approach of using advanced thermal and nonthermal processing. The aim is the foundation of "smart factories" along with sustainability parameters and ISO standard 14040 [12]. Our future is 3D/4D printing and farm robotics (from farm to industry) will be increasingly used in the food and agriculture sector and many of these technologies are considered to disrupt the food and agriculture 
systems. Whole approach is needed in agri-food sector from farm to industry and market, that needs to be included and considered, in terms of circular economy [13].

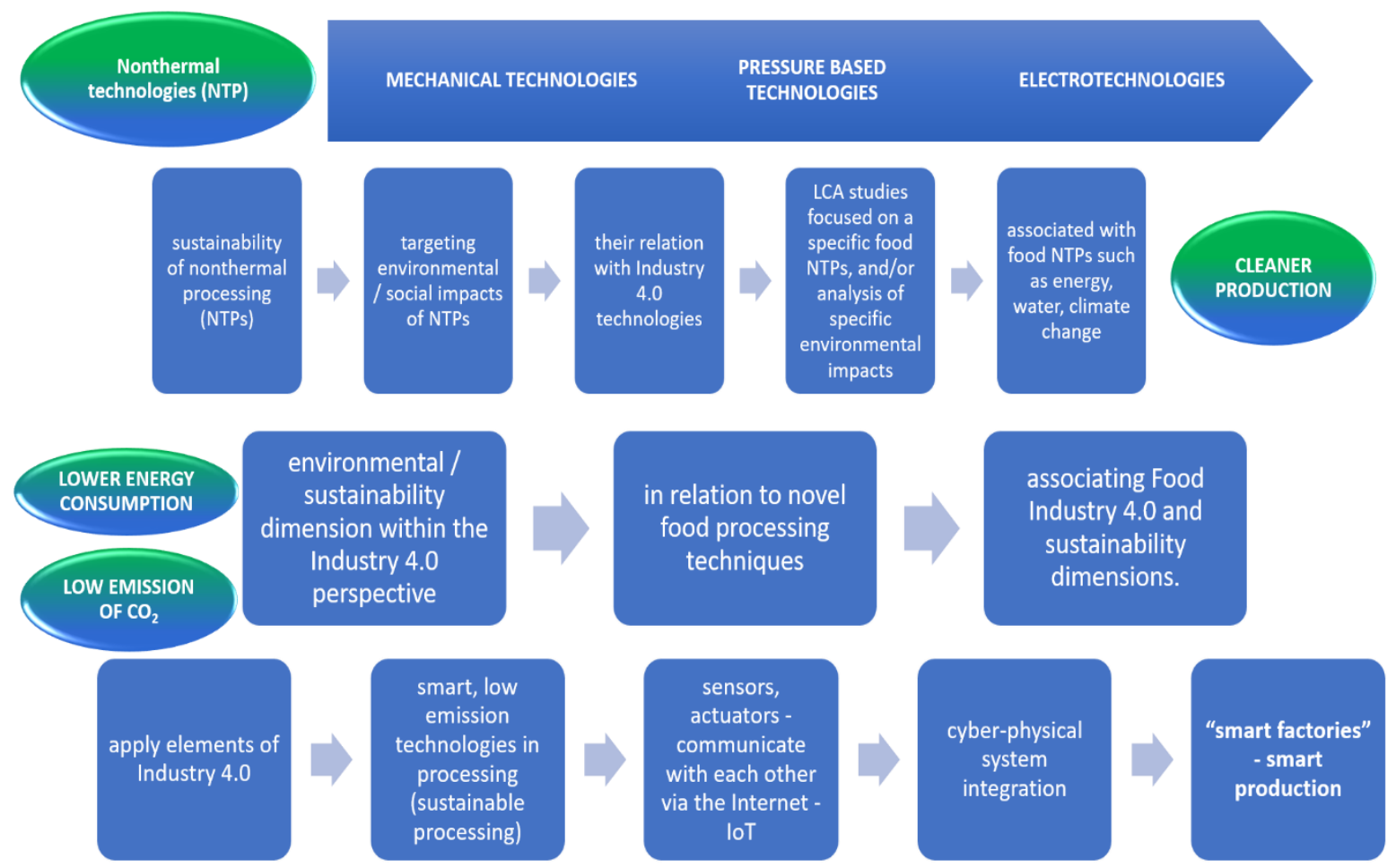

Figure 1. Nonthermal technologies in connection with elements of Industry 4.0 and sustainability dimensions.

Industry 4.0 includes automation and data exchange in manufacturing technologies and includes cyber-physical system, IoT, advanced connectivity and cloud-computing to transform production units into "smart factories". There is new concept-Agriculture 4.0 [14]. Agriculture 4.0 also discuss about data management and digitalization of data, in food and agriculture systems. System is supported by AI, IoT and automation, with the aim of creating a network of connected farms, machines and factories and achieving a high level of system optimization at the supply side (food production) and demand side (food consumption) [15].

Industry 4.0 emphasizes information and communication technology as one of four key technological areas: information and communication technology, technologies for assuring security of vital resources (food, water, and energy needs), new manufacturing and automation technologies.

What is needed are digital mesh, smart machines, smart hubs, digitalization, lean and green managements with circular economy. The usage of elements of Industry 4.0 in food processing as new 5th industrial revolution, will allow companies to combine advantages of modern technologies and also information and communication technology components, to increase productivity and speed to respond to the market. Safe cyber security will be making their system more productive and competitive. That is why there is need for cycle of Agriculture 4.0, Industry 4.0, cyber security, and lean and green management to assure new step in scale-up od technologies that reached high technology readiness level technology readiness level.

\subsection{Use of New Methods for Harvesting, Preservation, Transformation, and Extraction}

An important development on the food market is the demand for fresh like foods. Much research was done on minimal processing techniques to meet these demands. The central starting point is the knowledge of biochemical and microbiological processes, which cause deterioration of the quality of the products. With this knowledge and by 
combining several techniques in an intelligent way it is possible to slow down deterioration processes. Nevertheless, many food products are thermally sensitive and vulnerable to chemical, physical, and microbiological changes induced by conventional processing techniques for harvesting preservation, transformation, and extraction. Losses of some nutritional compounds, low production efficiency, long processing time, energy consuming procedures with prolonged heating and stirring, generation of large quantity of waste and by-products, need of number of ingredients to stabilize the final food formula, and use of large volumes of water encountered using these conventional food-processing methods. These shortcomings have led to the use of green and innovative techniques in harvesting, processing, pasteurization, and extraction, which typically involve less time, water, and energy. As a result of these findings, a SWOT analysis has been developed, with internal factors deployed to different technologies, while external factors, as common to all technologies, has been outlined as generic opportunities and threats (Table 1).

Table 1. SWOT analysis of novel food processing techniques.

\begin{tabular}{|c|c|c|}
\hline & POSITIVE & NEGATIVE \\
\hline & Strengths (S) & Weaknesses (W) \\
\hline \multirow[t]{2}{*}{ INTERNAL } & $\begin{array}{l}\text { Potential of adjusting technological parameters: } \\
\text { M-Selecting heating } \\
\text { M-Volumetric heating } \\
\text { M-Homogeneous heat treatment } \\
\text { M-Uniformity of heating } \\
\text { M-Selective heating } \\
\text { U-Cavitation through high frequency sound } \\
\text { waves } \\
\text { U-Collision of microjets with generation of high } \\
\text { pressure and temperature to breakdown cells } \\
\text { U-Reduction of process times } \\
\text { U-Mass transfer increased } \\
\text { U-Effect on enzyme activity } \\
\text { U-Batch or continuous operation } \\
\text { P-Ionized gas to produce free radicals, ions, } \\
\text { electrons, and other discharges } \\
\text { P-Reduced energy consumption temperature } \\
\text { P-Inactivation of pathogens } \\
\text { H-Ultra-high pressure, or high hydrostatic } \\
\text { pressure } \\
\text { H-Increase mass transfer rate of liquid oil }\end{array}$ & $\begin{array}{l}\text { Quality/food safety issues: } \\
\text { M-Overheating and quality damage } \\
\text { U-Unwanted modification of food structure } \\
\text { and texture } \\
\text { U-Possible modification of lipids and } \\
\text { generation of off flavors } \\
\text { P-Possible damage by free radicalsP-Reduce } \\
\text { food quality } \\
\text { P-Oxygen may cause food quality to decline } \\
\text { H-Changing physical properties such as } \\
\text { melting point, solubility, density, viscosity, and } \\
\text { chemical equilibrium } \\
\text { H-Difficulty for continuous processing }\end{array}$ \\
\hline & Opportunities (O) & Threats (T) \\
\hline EXTERNAL & $\begin{array}{l}\text { Infrastructural and economic issues: } \\
\text { A-Space savings in production area } \\
\text { A-Development of new markets } \\
\text { A-Development of new consumers groups }\end{array}$ & $\begin{array}{l}\text { Financial and knowledge issues: } \\
\text { A-Lack of experimental data needed to } \\
\text { modelling heating and/or other technological } \\
\text { parameters } \\
\text { A-Need of engineering to understand the new } \\
\text { technological processes } \\
\text { A-Potential problems with scaling up } \\
\text { A-Lack of qualified labor }\end{array}$ \\
\hline
\end{tabular}

Legend: (M)—Microwave; (U)—Ultrasound; (P)—Plasma; (H)—High pressure; (A)—applicable for all technologies.

Several novel and green food processing techniques are shown to be very prominent and of big interest for the food industry, especially PEF, US, microwave, PL, ohmic heating, irradiation, HPP and high voltage electric discharges (HVED). They are well known to have a significant effect on the rate of various processes in the food industry. Full reproducible food processes can now be completed in seconds or minutes with high reproducibility, reducing the processing cost, simplifying manipulation and work-up, giving higher purity of the final product, eliminating post-treatment of waste water and 
consuming only a fraction of the time and energy normally needed for conventional processes. The advantages of using novel green techniques or food processing, includes: more effective heating, faster energy transfer, reduced thermal gradients, selective heating, reduced equipment size, faster response to process heating control, faster start-up, increased production, and elimination of process steps [16].

\section{Tools-Industry 4.0}

\subsection{Artificial Intelligence (AI)}

High-quality production with minimal cost is the goal for most companies. Different initiatives of Industry 4.0 lead to that goal. One of the most promising is AI which has brought a revolution in all productions. Thus, manufacturing industries invest in AI technology more and more. AI could be defined like systems that think and act like humans, that think and act rationally [17]. AI is an interdisciplinary science with many approaches and thanks to development of machine learning and deep learning, AI has effects on all industries and technologies. AI transforms food industry too: from safety and quality issues, waste reduction, hygiene and cleaning tasks, environmental sustainability, production optimization, packaging to consumer insights [18-20].

AI systems assure safer, more accurate, faster, and more consistent production results than humans. Machine learning, video and image recognition tools can detect and analyze safety and quality issues improving modern approach to food production. Potential risks during food production can be detected using AI. Real-time monitoring by AI instead of waiting the end of production cycle to check output quality can identify errors and anomalies as soon as possible [21-23]. Multi-sensor systems with AI embedded show great potential for the optimization of the cleaning processes and hygiene in food industry $[24,25]$. AI has significant role in optimizing resource consumption (for example, power and water), which immediately creates reduction in production costs. Whole process powered by AI, including robotics, can be totally automated, working $24 \mathrm{~h}$ per day, 7 days a week [26]. Production management can be easier and more sustainable by reduction of power consumption [19]. Methods which include predictive machine learning algorithms can help operators to recognize issues before they become serious and complicate to solve without shutdown of the production. In order to meet and exceed key performance indicators AI will optimize production process developing methods for automated production calibration and increasing quality and speed of the production. An AI system collects data from smart sensors and with previous operation history predicts maintenance timing without breakdowns or shutdowns of production [27]. Robotics driven by AI is an important element in the sector of packing and delivering of food products because of increasing demands from final consumers [18,28-32]. Technological solutions founded on AI enable bigger, more quality food production with less inputs, less waste and lower energy consumption [20,31,33,34].

Technological solutions founded on AI enable bigger, more quality food production with less inputs, less waste and lower energy consumption.

\subsection{Industry of Things (IoT) and Industrial Internet of Things (IIoT)}

The IoT and services enables to optimize operational efficiency and rationalization, automation and maintenance of network for the entire factory to form a smart environment [35]. Industrial Internet of Things (IIoT), known as the Industrial Internet is term that brings together machinery, analytics (big data) and employees. It is the network of huge number of industrial devices connected by communications technologies that results in systems that can monitor, collect, exchange, analyze, and deliver valuable information. This is helping deliver smart, optimized solutions for specific industry in which smart machines are digitally connected and can communicate to each other. Information technologies (IT) and operational technologies (OT) are brought together in new term under IIoT. IIoT systems are combined with the cloud and analytics. There are three levels of connectivity: monitoring (data may be collected from machines); optimization (allows 
computers to process data) and automation (allows smart factories to self-regulate without any human interaction). What is also important is overall equipment effectiveness (OEE), that is a measure of how well a manufacturing operation is utilized (facilities, time, and material) compared to its full potential, during the periods when it is scheduled to run. IOT devices are industrial sensors, actuators, motors and controllers and they can deliver vital information that can help processing run more efficiently and cost effectively.

IoT can be efficiently implanted in food industry to reduce or eliminate downtime because of machine failure or damage, as well as reducing the overall cost of machine maintenance. IoT can provide staff with remote access to critical systems. Food processing is one of the largest sources of environmental impact and sustainable sectors have focused its sustainability efforts to reduce $\mathrm{CO}_{2}$ footprint, reduce waste, and to assure reduce, reduce, recycle principles. Processing food with minimal inputs including water, raw materials, and energy will reduce the total impact of food processing. IoT can be implemented in ways that reduce the level of food waste. IoT devices can be effectively used to improve food traceability and automate data collection. In that way it would be easy to track of where produce comes from, how it was transported and what kind of environmental conditions it has been subject. This will allow for employees to use digital information to manually increase efficiency and productivity [36].

All mentioned data, cloud, smart, digital, industry 4.0, IoT, IIoT, sensors, machines play a key role in the internet of everything. This is the reason why there are different terms like changes of Industry 4.0, smart factory as this is continuation of the phrase digital factory which was previously used. Therefore, basic principles of Industry 4.0 are connection of machines, systems and creating intelligent networks.

Thanks to Agriculture 4.0, many technologies make it possible to accomplish smart farms [15]. The interconnection from farm to form, it is necessary, and it is important to assure digitalization and smart systems from farm to fork. It is also of extreme importance to mention blockchain (digital data's) and cybersecurity. One example is Siemens, MindSphere: "generated data and information are collected in Siemens MindSphere-the cloud-based open IoT operating system. MindSphere buffers all useful information before forwarding only a critical subset to the Blockchain, which then represents a tamper proof chain of custody. Siemens Blockchain then makes sure the collected data is safe and transparently accessible to everyone who is part of the consortium".

\subsection{Additive Technologies}

As Industry 4.0 encourages the usage of smart manufacturing and sophisticated information technology, additive manufacturing presents its important element. Additive manufacturing is an automated process of creating three-dimensional (3D) physical objects directly from 3D computer-aided design (3D-CAD) data by adding material layer by layer. For that reason, it is also called a 3D printing [37].

The additive production is the result of a joint cooperation of experts from different fields of science. The interdisciplinarity required a maximum exploitation of the potential provided by additive production in order to push the boundaries of possible development and production of new products. Unlike conventional production techniques, such as subtractive and formative production, additive technologies form the final shape of product by adding materials [38,39]. With this technology, customized products with complex geometric shapes can be designed and printed using various edible ingredients [39].

The process of final product formation is presented in Figure 2. Firstly, the twodimensional (2D) model is designed in a CAD program. From 2D model, a 3D model can be created that represents the final shape of the product. Although various complex models can be created, the care should be taken with the thin and high models that can be which disintegrate during printing because they do not have a support from the bottom layers. Secondly, the created 3D model is transferred to the special computer software that cuts the model into horizontal slices (layers), such as Slic3r. Sliced model presents each layer that will be printed by a 3D printer. The software translates the model to the readable file format 
(i.e., G-code) for the printer. Finally, the model is sent to the printer where layer-by-layer, a material is added forming a final product. This product can be ready-to-eat or it can be additionally processed by heating or other processing methods in order to get a desired food product.

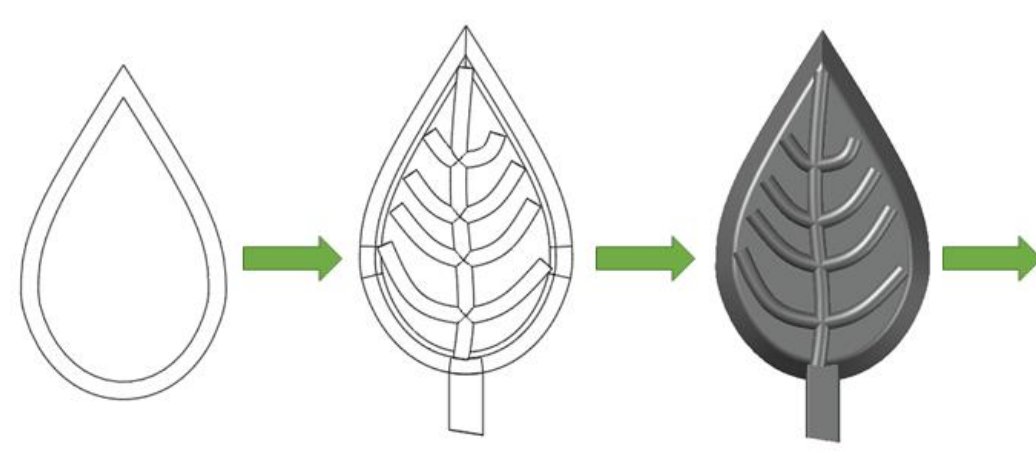

Creation of a 2D model in a CAD program

\section{Creation of a 3D} model from 2D model in a CAD program

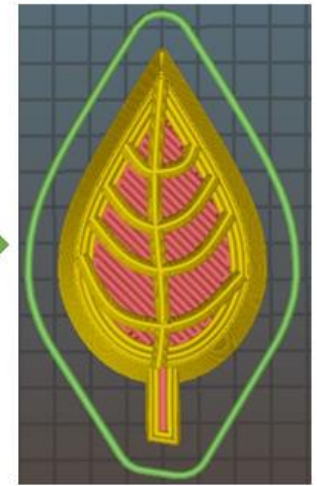

Final 3D model of the product
Layers of a 3D model cut in Slic3r software

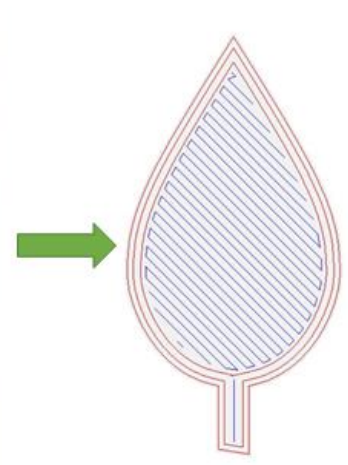

One layer sliced in Slic3r software that represents the way it will be printed

Figure 2. Process of product shape formation using additive manufacturing.

\subsubsection{Food Printing Methods}

The following 3D printing methods are available in the food sector: extrusion-based printing, selective sintering printing, binder jetting, and inkjet printing [40].

\section{Extrusion-Based Printing}

The extrusion-based printing, or fused deposition modelling, was invented in 1988 by Scott Crump to produce plastic objects. Nowadays, it became the main 3D food printing method. This technology is based on extrusion of semi-plastic materials from a movable head that is being deposited into ultra-thin layers. The material is being heated at temperatures that are slightly above the melting point so they can easily solidify after the extrusion that enabling layers to fuse [41].

This 3D printing technology is simple for use and applicable for different materials. Until now, it has been mostly used for paste-like materials such as tomato paste [42], potato starch [43], chocolate [44], aqueous chlorella microalgae suspensions and emulsions [45], and different starches [46]. The printing precision and properties of the final product mostly depend on chosen materials (rheological, mechanical and thermal properties, moisture content), processing parameters (nozzle diameter, printing height, movement rate) and post-processing treatment (cooking, freezing, drying) [41].

\section{Selective Sintering Printing}

Selective sintering printing is a technology where sintering source is laser or hot air that generate energy that allows fusion of particles together layer by layer into a final 3D structure. The laser scans cross-sections of the specific areas of each layer and selectively fuses the material [40]. This technology allows to apply different food material components to each layer. Therefore, a great advantage of selective sintering printing is that it is suitable for multi-printing materials. Moreover, the unfused material can be removed and reused for the next printing.

This technology is suitable for printing of powdered food materials such as sugar, starch and fat-based materials with relatively low melting points [47]. The printing precision with selective sintering is mainly affected by material properties (particle size, melting 
point, flowability, powder wettability), processing parameters (power, laser types, energy, laser spot diameter, scanning speed) and post-processing operations (removal of superfluous material). This technology is not entirely suitable for production of personalized and nutrient rich products, since thermosensitive nutrient composition could be significantly decreased when heat is applied for layers' fusion [40].

\section{Binder Jetting}

In the binder jetting 3D printing, a powdered material is deposited evenly layer by layer and the binder is selectively ejected upon each layer to bind two consecutive powder layers. As well as with selective sintering technology, the unfused material can be removed and recycled [47]. The advantage of this technology includes high printer speed, great variety of printable materials, it is suitable for complex and delicate 3D models and have the potential to create colorful 3D food products by varying different composition of the binder [40]. The main disadvantage of this technology is that printing material is limited only to powdered substances, high machine cost and rough surface finish of the final product. Moreover, a post-processing, such as curing at high temperatures or dehydration, may be required to improve its strength [41].

The printing precision is under the influence of material properties such as particle size and distribution of the powder, wettability and binder viscosity, processing factors including nozzle diameter, layer physical properties and printing rate, and post-processing operations like mentioned heating, baking, surface coating and removal of excess material [40].

\section{Inkjet Printing}

The technology of inkjet printing is based on dispense of droplets from a thermal or piezoelectric head for surface filling in certain regions such as decorations of products such as cakes, cookies or pizza [41]. Inkjet printers are suitable for low viscosity materials (chocolate, liquid dough, gels, jams), and is rather used to print drawing on flat moving products. Therefore, this technology is mainly used for decorations in pastry shops [48].

Inkjet printing precision is affected by material properties that mainly include rheological properties, and processing parameters like temperature, printing rate, nozzle diameter, and others. The main disadvantages of this technology include inability to produce complex food structures and the printed material cannot be recycled [41].

\subsubsection{Sustainability of Additive Manufacturing}

Additive manufacturing has been successfully developing in a last decade mostly due to the technical advantages of this technology that exceed the possibilities of traditional methods. Such advantages include quite fast and simple production of complex food structures and geometries, customized products, and reduced material waste due to possibility of recycling [49].

Additive manufacturing is considered as clean and green production that brings key environmental benefits manifested through three main aspects: resource consumption, waste management and pollution control. The majority of resource consumption refers to the electricity that drives the system and to the material used for printing (filaments, polymers, powders). The efficiency of the material using additive techniques is about $97 \%$, which minimizes the amount of waste, for example, compared to conventional subtractive production [50]. Subtractive production generates a large amount of waste and additive production can reduce the amount of waste by as much as $90 \%$. However, this does not mean that additive manufacturing does not produce any waste. The majority of additive production waste consists of unexpected damage to this support structure if the method requires it. Compared to other production techniques, less pollution is created because non-toxic materials and green chemicals are most commonly used [49,51].

Even though there are some disadvantages of additive manufacturing, some key environmental benefits can be expected (Figure 3). Additive production reduces the need for energy-intensive and polluting production processes. The advantage of this production 
is efficient and more flexible product design with better performance, it is possible to decentralize production and reduce $\mathrm{CO}_{2}$ emissions during the production process, which directly affects the carbon footprint. Consequently, time and cost effect can be potentially reduced, especially for individualized and small manufactures $[40,49,51]$.

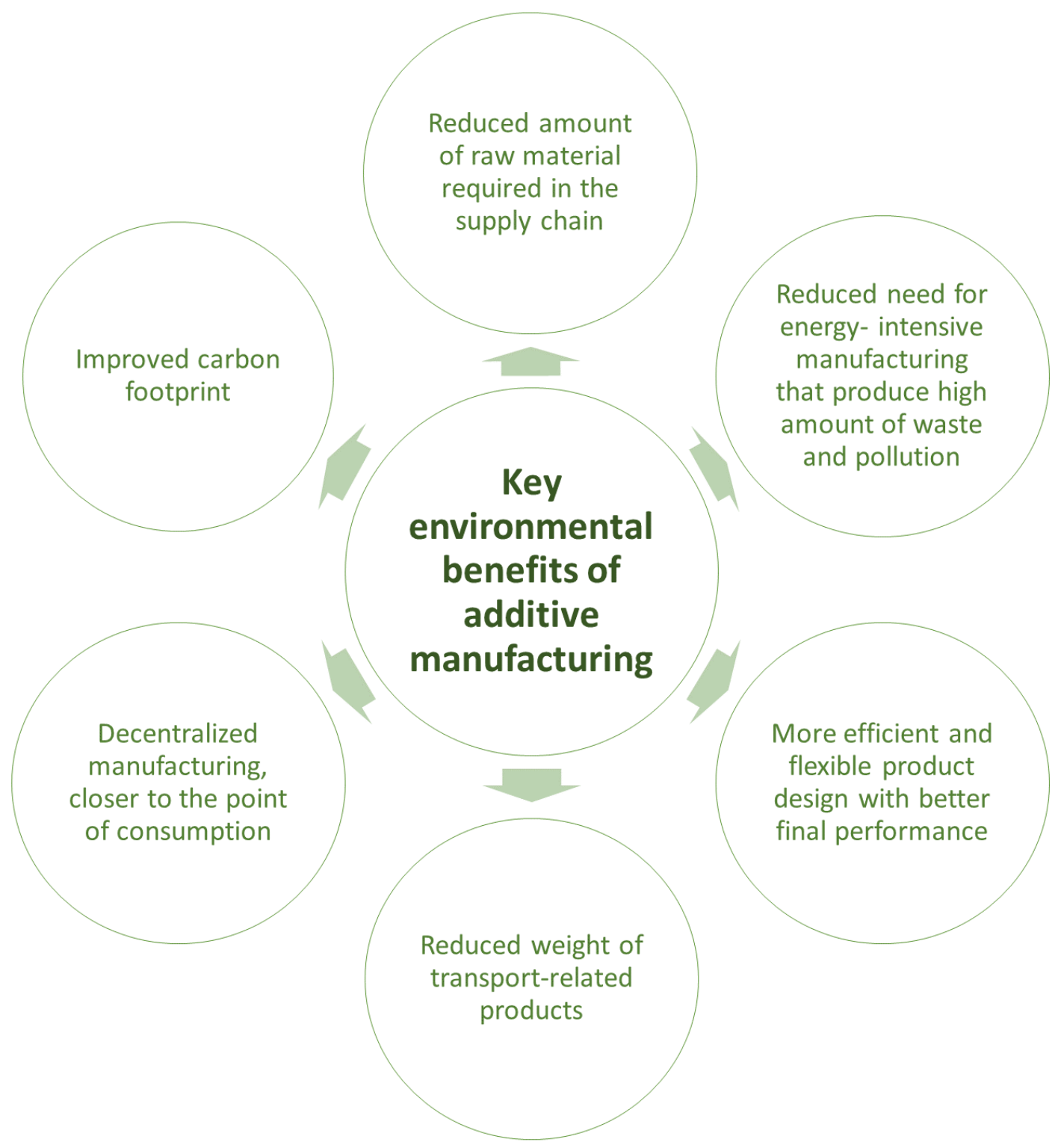

Figure 3. Environmental benefits of additive manufacturing.

A great example of sustainable application od additive manufacturing is given by a Dutch startup company Upprinting Food who recycle food waste and produce 3D printed snacks. Such food include bread, fruits and vegetables that are not eligible for selling but are still edible and food residues from restaurants [52].

A physical part of the smart factories is limited by the availability of the existing manufacturing systems. This makes the additive manufacturing as one of the vital components of Industry 4.0. Finally, additive manufacturing is expected to become a key manufacturing technology for fabricating customized products in a sustainable society in the future. It is believed that it has a potential to revolutionize manufacturing industry and offers a way to replace the conventional manufacturing technologies [53]. Davis and Garret pointed out that 3D printing could be one of technologies useful for developing 
sustainable urban food ecosystems as a result to the increasing world population and limited availability of resources [54].

\subsection{Big Data}

It is obvious that food industry 4.0 strives to integrate communication, information and intelligence technologies where big data play a significant role [55]. Data management comprises of acquiring data in a more timely, rapid and flexible manner [56]. One of typical attributes associated with big data is high volume, velocity and variety of information with constraints in managing data [57].

The main challenges when speaking about big data in industry 4.0 food sustainability perspective is how to model and explore various agri-food policies using multi-source data and intelligent tools. To mention the complexity of food industry 4.0, the following food sustainability data associated with non-thermal technologies should be emphasized [13,58]: (i) environmental issues; (ii) economic issues; (iii) social issues; (iv) consumer preferences associated with food quality; (v) nutritional issues; (vi) food hygiene issues; (vii) purchasing patronage issues. Key issues to be resolved when developing data architecture is data quality, data uncertainty and the potential for data analytics [13].

In the EU, two dimensions determine Industry 4.0 in the context of manufacturing companies-'Infrastructure' in terms of hardware and communication network opposed to 'Big data maturity' in the context of processing information though the infrastructure [59]. The potential of extracting and interpreting data within (food) manufacturing processes and/or (food) supply chains can increase effectiveness and facilitate all types of nonconformities [60]. Existence of analytical capacities is in relation to the use of various mathematical models in the food sector [61]. Results from this cross-European study reveals on one side big food companies and companies operating in developed parts of Europe with a higher level of applied modelling compared to small and medium-sized companies and companies operating in less developed parts of Europe. One of the reasons for low level of modelling and (big) data analysis in the food sector is due to the novelty of such a topic, slow food companies adaptation to it opposed to fast development of this sector demanding reengineering of existing food manufacturing processes [59]. Food sector per se has not been in focus of overall assessment of Industry 4.0 readiness, with limited evaluating models developed [62].

\subsection{Smart Sensors}

Global food demands are continuously increasing, which means that the efficiency and effectiveness of agricultural production and food technology must be increased. In doing so, various available tools and techniques could be used, and new ones are developed. In general, research and development of new technologies such as sensor technologies or Internet technologies and wireless communications leads to the need to introduce them in the food industry. The IoT allows the integration of a large number of devices with a network of embedded specific sensors that communicate independently with each other and with different applications. This provides data that can be analyzed and then used in automated work as a first step, and later for planning, management, strategy development, and decision making. Collecting large amounts of product data in the Food Industry 4.0. requires the use of smart sensors and stable, predictive, and reliable communications [63]. Smart sensors have proven to be an excellent alternative to traditional methods and promising tools for all investigations and applications [63-65].

Smart modules and sensors can be added in processing line and to monitor specific part of processes. The whole range of added modules can be plug and play or lightly programmed. An example of connecting subsequent modules can be an Arduino. In article by Roman et al., [66] sampler 2.5 dust measurement module has been connected as an Arduino module. This illustrates how technology can be developed and how standardization of libraries allows rapid development. 
Biosensors as devices for converting biological quantity into electrical signal are widely used in the food industry due to their specifics: short response time, high sensitivity, fast detection, automation capability, relatively low production cost, simple real-time management and monitoring, simple installation in integrated systems, easy integration into various methods to ensure food quality and safety. Biosensors can be designed for either specific compounds or a selected class of food, which greatly expands their field of application. The design of the biosensor can be in portable form, which allows monitoring of the product during the production itself, but also during distribution and selling. Effective risk management in the food industry is greatly facilitated using biosensors $[67,68]$. Classification of biosensors according principles and measurands is shown in Table 2.

Table 2. Principles and measurands of some typical biosensors.

\begin{tabular}{cc}
\hline Principle & Measurand \\
\hline Conductometric & Resistance/conductance \\
Potentiometric & Voltage/e.m.f. \\
Capacitive & Capacitance/charge \\
Amperometric & Current \\
Calorimetric & Heat/temperature \\
Gravimetric & Mass \\
Optical & Path length/absorption \\
Resonant & Frequency \\
Fluorescent & Intensity \\
\hline
\end{tabular}

Biosensors are subgroup of chemical sensors where the element is a biologically active material: enzyme, antibody, biological chemical, tissue, cell and organelles. The combination of all above-mentioned elements of biorecognition and principles allows the development of many types of biosensors. However, most commercial biosensors used in food industry are based on enzymes or antibodies as the most commonly used biologically active elements [69-73].

Enzymes are large protein molecules that catalyze chemical reactions. Their task is to convert A (the original measurand) into one of the products $B$ while keeping the enzyme unchanged. The final product $B$ is directly measured by a (physical) sensor. In the human body, the role of enzymes is practically irreplaceable. Substance A always must be converted to substance $B$, and never, for example, to $C$, so enzymes must be able to detect the difference in a single atom that will show whether or not a chemical reaction will occur. This inherent selectivity of the enzyme is used in biosensors. A similar situation is with antibodies as a biologically active material. Antibodies are proteins produced by the immune system in response to "foreign" material in the body (antigen), such as viruses, bacteria, various implants... The fundamental difference between enzymes and antibodies is that antibodies do not catalyze chemical reactions but bind tightly to antigens ("foreign" material), thus marking them for the immune system for removal or attack. Antibodies should be extremely selective in antigen selection and this characteristic is used in biosensors. After binding of the antibody to the antigen, the antibody/antigen complex is exposed to a (physical) sensor, which thus changes some of the corresponding parameters measured by this (physical) sensor $[67,68]$.

Regardless of the good performance and the importance of using enzyme-based biosensors in the food industry, some other aspects must be considered before the commercialization of enzyme biosensors. A great advantage of enzyme-based biosensors is the immobilization of biological material on the electrode surface and better interface function. Polymers and nanomaterials are often used as carriers of biological material, and their main characteristics are an increase in the speed and stability of electron transfer and an extension of the life of biosensors $[64,65,69,71,74,75]$. The development of biocompatible materials must go in the direction of improving the sensitivity of biosensors. Extending the interval of use of biosensors must be accompanied by improving the immobilization technology and 
modifying the enzymes on which they work [75]. Sample pre-treatment and optimization of biosensor specificity and selectivity reduces unwanted interactions [76]. The significant diversity of enzymes and enzymatic reactions indicates the need for careful selection for each biosensor which will result in the desired results. The biggest possible problems with biosensors are sterilization, contamination and sometimes cost. Sterilization is almost always necessary for in situ use, so particular characteristics of biosensor are changed. It further means deviation from the original calibration of the sensor with all potential consequences. Contamination involves the risk that used biological material/chemicals will leak and come into contact with the environment (human tissue). The cost of production of individual sensors, no matter how technically attractive they are, is very high, so they are not mass-produced at all $[63,64,73]$.

The last few years a research of application of biosensors in agronomy and the food industry significantly increases, which implies that they play very important role in this field $[63,70,72,73,77-82]$.

\subsection{Smart Factories}

It all started with Programmable Logic Controller (PLC). PLC is an industrial digital computer that continuously monitors the state of input devices to make decisions (to control manufacturing processes and equipment) based on pre-programmed logic [83]. Now we have different kind of technical terms like Radio Frequency Identification (RFID), that is a wireless communication technology that uses radio frequency identify people or object. Supervisory Control and Data Acquisition (SCADA) is a control system architecture that uses computers and networked data communications to monitor and control factory floor equipment. IoT can enable the creation of virtual networks to support the smart factory in Industry 4.0, and the entire value chain that can control each other autonomously. IoT allows the machines to communicate (M2M) and this means more human free manufacturing environment $[84,85]$. The systems are becoming more and more "autonomous" and with sensors and CPS are the core elements of transformation to smart factories. Smart factory is a move from the traditional automation of the past to connected systems that makes use of data to cope with increasing business demands. Industry 4.0., is driving digital transformation across smart factories. It is blending computing power with machine and sensor technologies. As previously said, IoT systems can collect manufacturing data in a transparent, comprehensive, and interactive way. These tools can provide real-time visibility into assets and equipment, quality of processes and factory resources. Many innovative procedures have already been introduced, for instance, 3D printing or virtual reality [86]. To build smart factory it is necessary that management invest in technologies like cloud computing, IoT, advanced sensor technologies, 3D printing, industrial robotics, data analytics, AI, machine learning, enhanced machine-to-machine (M2M) communication along with building the capability of the employees. It is also possible, besides smart production to predict and estimate the production workflow. This is possible by collecting data that can produce digital factory simulations that predict how a product is expected to be manufactured. This is called virtual factory and that is real-time simulation of how production is manufactured.

\section{Sustainability of NTPs in Industry 4.0}

Many authors confirm that Industry 4.0 technologies have the potential of growth, competitiveness and industrial sustainability improvements $[87,88]$. The agri-food sector has also started using advantages of this technology in terms of utilizing modern equipment, emerging information and communication technologies, joint with sensing, smart and sustainable technologies [89]. One approach in understanding sustainability in Industry 4.0 is associating the SDGs of the UN with the food supply chain through the prism of Food Industry 4.0 as depicted in Figure 4. Out of 17 SDGs, eight can be recognized as directly or indirectly connected with food [90]. Tools outlined in Figure 4 comprise of various Industry 4.0 technologies $[89,91,92]$ applicable in the food supply chain. 


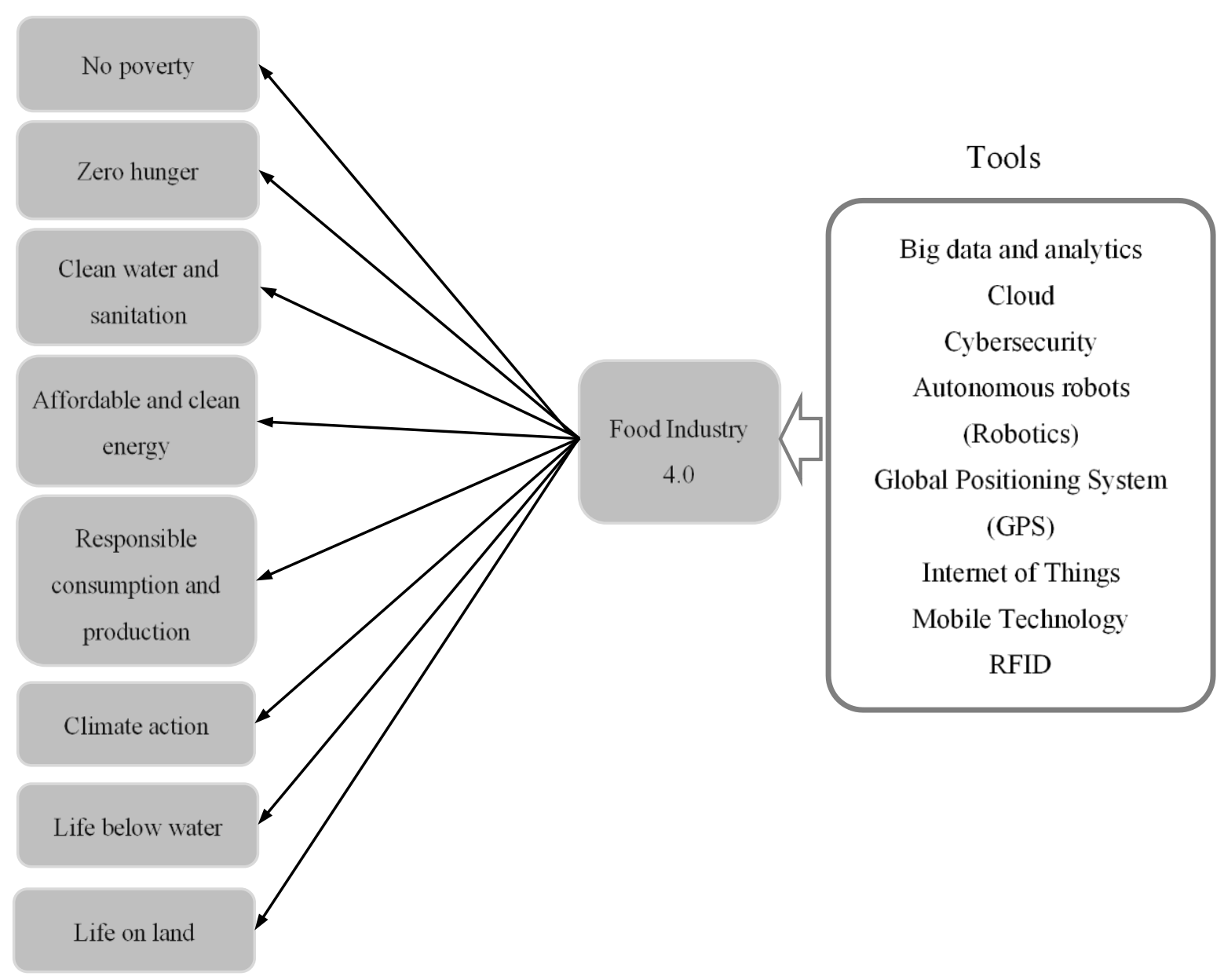

Figure 4. SDGs and Food Industry 4.0.

Food industry 4.0 can provide more basic resources and services to the poor people and bring them out of poverty [91], promote sustainable agriculture, sustainable food consumption and production patterns [93], provide new technologies for clean drinking water and sanitation [94], and combat climate change [95].

The social dimension of sustainability requires additional attention [91], where evaluation could be performed through the prism of poverty, inequality, prosperity, and peace and justice concerns [96]. The fourth Industrial revolution has the potential of addressing environmental and social issues upgrading the conventional technologies [97], and improving competitiveness justifying its economic dimension [91]. Food industry 4.0 has the possibility of reducing costs joint with production flexibility and higher productivity $[98,99]$, where known attributes of non-thermal technologies such as short treatment time and higher quality/food safety values [58], widen the economic perspective. Speaking about food industry 4.0, non-thermal technologies need to find their place in the cyber space between physical (conventional food manufacturing) and digital technologies [91].

Besides the economic and social dimensions, of sustainability, environmental dimension on non-thermal technologies was not fully explored by scientist due to several obstacles in terms of differences in scales of the non-thermal units (lab scale vs industrial facility) [100], type of food products in focus (animal origin vs plant origin, physical state of the product-powder, solid, liquid) and constraints in using LCA approach [58]. Partial LCA approach is typically used to evaluate the environmental impact of nonthermal food processing technologies mapping the lab-scale process, setting scope and boundaries an defining the functional unit (FU) as an output reference as $1 \mathrm{~kg} / 1 \mathrm{~L}$ of treated food product or even 1 treatment [4]. 
Challenges in performing a LCA of nonthermal food processing technologies is displayed in Table 3, deployed through its main elements: mapping the process, setting the scope and boundaries, collecting data, calculating, evaluating and interpreting the results [12]. The Table 3 has been developed in line with research from [100] and [4].

Table 3. Challenges in performing a LCA of nonthermal food processing technologies.

\begin{tabular}{|c|c|c|c|}
\hline No & Stage & Challenge & Issues to Be Resolved \\
\hline 1 & Scope and goal & Imprecise system boundaries & What are the boundaries of the lab scale unit? \\
\hline 2 & Scope and goal & Unreliable functional units & $\begin{array}{l}\text { Are results comparable or highly dependable on } \\
\text { functional units ( } 1 \mathrm{~kg} \text { of product vs } 1 \text { treatment)? }\end{array}$ \\
\hline 3 & Scope and goal & $\begin{array}{l}\text { Inadequate data collection } \\
\text { method }\end{array}$ & $\begin{array}{l}\text { Do inconsistent methods employed (measurement, } \\
\text { estimation, combination, re-calculation ... ) enhance } \\
\text { propagation of bias? }\end{array}$ \\
\hline 4 & Inventory analysis & $\begin{array}{l}\text { Material and energy flows and } \\
\text { waste streams }\end{array}$ & $\begin{array}{c}\text { Is it possible to precisely measure all } \\
\text { material/energy flows and outputs in a lab-scale } \\
\text { unit? }\end{array}$ \\
\hline 5 & Impact assessment & Choice of environmental impacts & $\begin{array}{l}\text { In which environmental impacts should the result be } \\
\text { displayed to enable comparisons? }\end{array}$ \\
\hline 6 & Interpretation of results & Uncertainty and sensitivity & $\begin{array}{l}\text { How do choice of functional unit, collection } \\
\text { methods and inventory analysis affect chosen } \\
\text { environmental impacts? }\end{array}$ \\
\hline
\end{tabular}

Since lab-scale units are usually at a technology readiness level between 3 and 4, it is necessary to clearly define boundaries of the system in which the partial LCA is used. Inconsistent functional unit raises a certain risk [4] since adequate choice should enable their comparison in-between food products and food technologies. Based on the data collection methods, it is important to be able to validate the data and relate them to nonthermal food processing technologies and chosen FUs [12].

Although inventory analysis of a partial LCA (for a lab-scale unit) may seem simple, main issues is the potential of precise measuring of input (material and energy) and output flows (waste/discharge streams) especially since in some cases, these values may be hard to measure. Some authors state that this stage is of significant importance in LCA since it provides values od unit process data [101].

As an outcome of partial LCA, it is necessary to calculate all environmental impacts and express them per FU. However, depending on the approach/software used, different impacts may be considered [4]. Due to all challenges mentioned and potential uncertainties, it would be more than good to perform a sensitivity analysis and clearly identify influencers (from the inventory analysis) within a sensitivity analysis.

To conclude the analysis of Food Industry 4.0 in relation to sustainability dimensions, a SWOT analysis has been performed, considering some similar publications [102-105] and it is presented in Table 4 .

It is obvious that food industry 4.0 has many advantages within all three sustainability dimensions. However, high initial investments, lack of knowledge among workers for using some (or all) of Industry 4.0 technologies and potential food safety risks still represent a challenge in implementing these technologies throughout the food supply chain. 
Table 4. The sustainability SWOT analysis for Food Industry 4.0.

\begin{tabular}{|c|c|c|}
\hline & POSITIVE & NEGATIVE \\
\hline & Strengths (S) & Weaknesses (W) \\
\hline \multirow[t]{2}{*}{ INTERNAL } & $\begin{array}{l}\text { En-Potential for energy saving during food processing } \\
\text { En-Optimized overall environmental performance } \\
\text { Ec-Lower manufacturing cost } \\
\text { Ec-Development of eco-friendly products } \\
\text { So-Higher level of health and safety during food processing } \\
\text { So-Better work condition for workers }\end{array}$ & $\begin{array}{l}\text { Ec-Need for investments } \\
\text { Ec-Budget need for training/research } \\
\text { So-Resistance to change management } \\
\text { En-Disbalance between environmental and } \\
\text { economic benefits of some I4.0 technologies }\end{array}$ \\
\hline & Opportunities (O) & Threats (T) \\
\hline EXTERNAL & $\begin{array}{l}\text { Ec-Better market share } \\
\text { Ec-New business models } \\
\text { Ec-Competitive advantage } \\
\text { So-Higher reputation } \\
\text { En-Striving towards "zero" pollution }\end{array}$ & $\begin{array}{l}\text { Ec-Slow return of investment } \\
\text { Ec-Food safety hazards from some I } 4.0 \\
\text { technologies } \\
\text { Ec-Consumers skeptical about new food } \\
\text { technologies } \\
\text { Ec-Demand of these food products may be } \\
\text { unpredictable } \\
\text { Ec-Need for changing consumer buying } \\
\text { behavior } \\
\text { So-Lack of knowledge among workers }\end{array}$ \\
\hline
\end{tabular}

Legend: (En)—environmental dimension; (So)—social dimension; (Ec)—economic dimension.

\section{Conclusions and Future Trends}

The review paper is giving an overview of applying nonthermal processing, with optimization of processing (sensors, IoT, big data, AI) with the aim of creating smart processing and smart factories. It is of high importance to perform LCA, to quantify (En)—environmental dimension; (So)—social dimension and (Ec)—economic dimension. A performed SWOT analysis for Food Industry 4.0 showed: potential for energy saving during food processing; optimized overall environmental performance; lower manufacturing cost; development of eco-friendly products; higher level of health and safety during food processing and better work condition for workers. When thinking of the future and innovative processes and technologies, we come to Industry 5.0. It will bring back communication between humans and machines, and it starts when we ask consumers what they want. We need to focus on consumers and ask what they want, do they understand technology, explain to them water, waste, carbon footprints, take care for the environment and society. The main responsibility of the research community is to develop technological infrastructure and scale-up to industry. It is necessary to have interdisciplinary research and contribution because we need technologists, engineers, economists, environmental scientists, and LCA managers. A necessity to describe physical systems, management models, business models as well as some defined Industry 4.0 and 5.0 models is needed. Running a more sustainable, energy-efficient food manufacturing facility allows the use of technology to minimize waste, carbon, and water footprint.

Author Contributions: Conceptualization, A.R.J.; writing—review and editing, A.R.J., M.N., I.D., S.P. and F.C.; validation, A.R.J., I.D. and F.C. All authors have read and agreed to the published version of the manuscript.

Funding: The authors A.R.J., M.N., S.P. and F.C. would like to thank to Croatian Science Foundation: "High voltage discharges for green solvent extraction of bioactive compounds from Mediterranean herbs" grant number [IP-2016-06-1913]. The work of doctoral student Marinela Nutrizio has been fully supported by the "Young researchers' career development project-training of doctoral students" of the Croatian Science Foundation funded by the European Union from the European Social Fund.

Institutional Review Board Statement: Not applicable.

Informed Consent Statement: Not applicable. 
Data Availability Statement: Data is contained within the article. The data presented in this study are available in article.

Conflicts of Interest: The authors declare no conflict of interest.

\section{References}

1. Picart-Palmade, L.; Cunault, C.; Chevalier-Lucia, D.; Belleville, M.P.; Marchesseau, S. Potentialities and limits of some non-thermal technologies to improve sustainability of food processing. Front. Nutr. 2019, 5, 130. [CrossRef]

2. Stasiulaitiene, I.; Martuzevicius, D.; Abromaitis, V.; Tichonovas, M.; Baltrusaitis, J.; Brandenburg, R.; Pawelec, A.; Schwock, A. Comparative life cycle assessment of plasma-based and traditional exhaust gas treatment technologies. J. Clean. Prod. 2016, 112, 1804-1812. [CrossRef]

3. Cacace, F.; Bottani, E.; Rizzi, A.; Vignali, G. Evaluation of the economic and environmental sustainability of high pressure processing of foods. Innov. Food Sci. Emerg. Technol. 2020, 60. [CrossRef]

4. Djekic, I.; Pojić, M.; Tonda, A.; Putnik, P.; Bursać Kovačević, D.; Režek-Jambrak, A.; Tomasevic, I. Scientific Challenges in Performing Life-Cycle Assessment in the Food Supply Chain. Foods 2019, 8, 301. [CrossRef] [PubMed]

5. Jambrak, A.R.; Donsì, F.; Paniwnyk, L.; Djekic, I. Impact of Novel Nonthermal Processing on Food Quality: Sustainability, Modelling, and Negative Aspects. J. Food Qual. 2019, 2019, 2171375. [CrossRef]

6. Wang, L. Energy efficiency technologies for sustainable food processing. Energy Effic. 2014, 7, 791-810. [CrossRef]

7. von der Gracht, H.A. Consensus measurement in Delphi studies. Review and implications for future quality assurance. Technol. Forecast. Soc. Chang. 2012, 79, 1525-1536. [CrossRef]

8. Santos, J.; Muñoz-Villamizar, A.; Ormazábal, M.; Viles, E. Using problem-oriented monitoring to simultaneously improve productivity and environmental performance in manufacturing companies. Int. J. Comput. Integr. Manuf. 2019, 32, 183-193. [CrossRef]

9. FAO. E FAO Regional Conference for Asia and the Pacific Bytes to Sustain Our Bites: Leveraging Digital Agriculture For Sustainable Development Goals (SDGs). In Proceedings of the FAO Regional Conference for Asia and the Pacific, APRC/20/9, Thimphu, Bhutan, 1-4 September 2020.

10. Ras, E.; Wild, F.; Stahl, C.; Baudet, A. Bridging the skills gap of workers in industry 4.0 by human performance augmentation tools-Challenges and roadmap. In Proceedings of the 10th International Conference on PErvasive Technologies Related to Assistive Environments, Island of Rhodes, Greece, 21-23 June 2017; Volume Part F128530, pp. 428-432.

11. Gusmão Caiado, R.G.; Leal Filho, W.; Quelhas, O.L.G.; Luiz de Mattos Nascimento, D.; Ávila, L.V. A literature-based review on potentials and constraints in the implementation of the sustainable development goals. J. Clean. Prod. 2018, 198, 1276-1288. [CrossRef]

12. ISO. ISO 14040:2006 Environmental Management_Life Cycleassessment_Principles and Framework; Technical Committee: ISO/TC 207/SC 5 Life Cycle Assessment: ICS: 13.020.10 Environmental Management 13.020.60 Product Life-Cycles; ISO: Geneva, Switzerland, 2006.

13. Belaud, J.P.; Prioux, N.; Vialle, C.; Sablayrolles, C. Big data for agri-food 4.0: Application to sustainability management for by-products supply chain. Comput. Ind. 2019, 111, 41-50. [CrossRef]

14. Latino, M.E.; Corallo, A.; Menegoli, M. From Industry 4.0 to Agriculture 4.0: How Manage Product Data in Agri-Food Supply Chain for Voluntary Traceability, A Framework Proposed. Innovators Network of Innovative Entities View Project KHIRA-Knowledge Based Holistic Integrated Research Approach View Project; World Academy of Science, Engineering and Technology: Istanbul, Turkey, 2018.

15. Zambon, I.; Cecchini, M.; Egidi, G.; Saporito, M.G.; Colantoni, A. Revolution 4.0: Industry vs. Agriculture in a Future Development for SMEs. Processes 2019, 7, 36. [CrossRef]

16. Chemat, F.; Rombaut, N.; Meullemiestre, A.; Turk, M.; Perino, S.; Fabiano-Tixier, A.-S.; Abert-Vian, M. Review of Green Food Processing techniques. Preservation, transformation, and extraction. Innov. Food Sci. Emerg. Technol. 2017. [CrossRef]

17. Artificial Intelligence: A Modern Approach: Russell, Stuart, Norvig, Peter: 8601419506989. Available online: Amazon.com (accessed on 15 December 2020).

18. Kakani, V.; Nguyen, V.H.; Kumar, B.P.; Kim, H.; Pasupuleti, V.R. A critical review on computer vision and artificial intelligence in food industry. J. Agric. Food Res. 2020, 2, 100033. [CrossRef]

19. Di Vaio, A.; Boccia, F.; Landriani, L.; Palladino, R. Artificial intelligence in the agri-food system: Rethinking sustainable business models in the COVID-19 scenario. Sustainability 2020, 12, 4851. [CrossRef]

20. Misra, N.N.; Dixit, Y.; Al-Mallahi, A.; Bhullar, M.S.; Upadhyay, R.; Martynenko, A. IoT, big data and artificial intelligence in agriculture and food industry. IEEE Internet Things J. 2020. [CrossRef]

21. Goyache, F.; Bahamonde, A.; Alonso, J.; Lopez, S.; Del Coz, J.J.; Quevedo, J.R.; Ranilla, J.; Luaces, O.; Alvarez, I.; Royo, L.J.; et al. The usefulness of artificial intelligence techniques to assess subjective quality of products in the food industry. Trends Food Sci. Technol. 2001, 12, 370-381. [CrossRef]

22. Funes, E.; Allouche, Y.; Beltrán, G.; Jiménez, A. A Review: Artificial Neural Networks as Tool for Control Food Industry Process. J. Sens. Technol. 2015, 5, 28-43. [CrossRef] 
23. Garcia-Esteban, J.A.; Curto, B.; Moreno, V.; Gonzalez-Martin, I.; Revilla, I.; Vivar-Quintana, A. A digitalization strategy for quality control in food industry based on Artificial Intelligence techniques. In Proceedings of the IEEE 16th International Conference on Industrial Informatics, INDIN 2018, Porto, Portugal, 18-20 July 2018; Institute of Electrical and Electronics Engineers Inc.: New York, NY, USA, 2018; pp. 221-226.

24. Talaviya, T.; Shah, D.; Patel, N.; Yagnik, H.; Shah, M. Implementation of artificial intelligence in agriculture for optimisation of irrigation and application of pesticides and herbicides. Artif. Intell. Agric. 2020, 4, 58-73. [CrossRef]

25. Helmy, M.; Smith, D.; Selvarajoo, K. Systems biology approaches integrated with artificial intelligence for optimized metabolic engineering. Metab. Eng. Commun. 2020, 11, e00149. [CrossRef]

26. Iqbal, J.; Khan, Z.H.; Khalid, A. Prospects of robotics in food industry. Food Sci. Technol. 2017, 37, 159-165. [CrossRef]

27. Jung, J.; Maeda, M.; Chang, A.; Bhandari, M.; Ashapure, A.; Landivar-Bowles, J. The potential of remote sensing and artificial intelligence as tools to improve the resilience of agriculture production systems. Curr. Opin. Biotechnol. 2021, 70, 15-22. [CrossRef] [PubMed]

28. da Silva e Silva, N.; de Souza Farias, F.; dos Santos Freitas, M.M.; Pino Hernández, E.J.G.; Dantas, V.V.; Enê Chaves Oliveira, M.; Joele, M.R.S.P.; de Fátima Henriques Lourenço, L. Artificial intelligence application for classification and selection of fish gelatin packaging film produced with incorporation of palm oil and plant essential oils. Food Packag. Shelf Life 2021, 27, 100611. [CrossRef]

29. Naranjo-Torres, J.; Mora, M.; Hernández-García, R.; Barrientos, R.J.; Fredes, C.; Valenzuela, A. A Review of Convolutional Neural Network Applied to Fruit Image Processing. Appl. Sci. 2020, 10, 3443. [CrossRef]

30. Wauters, T.; Verbeeck, K.; Verstraete, P.; Vanden Berghe, G.; De Causmaecker, P. Real-world production scheduling for the food industry: An integrated approach. Eng. Appl. Artif. Intell. 2012, 25, 222-228. [CrossRef]

31. Soltani-Fesaghandis, G.; Pooya, A. Design of an artificial intelligence system for predicting success of new product development and selecting proper market-product strategy in the food industry. Int. Food Agribus. Manag. Rev. 2018, 21, 847-864. [CrossRef]

32. Grumezescu, A.; Holban, A.M. Engineering Tools in the Beverage Industry; Woodhead Publishing: Cambridge, UK, 2019.

33. Dolci, R. IoT Solutions for Precision Farming and Food Manufacturing: Artificial Intelligence Applications in Digital Food. In Proceedings of the 2017 IEEE 41st Annual Computer Software and Applications Conference (COMPSAC), Turin, Italy, 4-8 July 2017; IEEE Computer Society: New York, NY, USA, 2017; Volume 2, pp. 384-385.

34. Chun, K.-S. Why Artificial Intelligence is important for ethnic foods? J. Ethn. Foods 2018, 5, 75. [CrossRef]

35. Manavalan, E.; Jayakrishna, K. A review of Internet of Things (IoT) embedded sustainable supply chain for industry 4.0 requirements. Comput. Ind. Eng. 2019, 127, 925-953. [CrossRef]

36. Köbnick, P.; Velu, C.; McFarlane, D. Preparing for industry 4.0: Digital business model innovation in the food and beverage industry. Int. J. Mechatron. Manuf. Syst. 2020, 13, 59-89. [CrossRef]

37. Gebhardt, A. Understanding Additive Manufacturing; Carl Hanser Verlag GmbH \& Co. KG: Munich, Germany, 2011.

38. Huang, S.H.; Liu, P.; Mokasdar, A.; Hou, L. Additive manufacturing and its societal impact: A literature review. Int. J. Adv. Manuf. Technol. 2013, 67, 1191-1203. [CrossRef]

39. Khanpara, P.; Tanwar, S. Additive Manufacturing: Concepts and Technologies; Springer: Cham, Switzerland, $2020 ;$ pp. 171-185.

40. Liu, Z.; Zhang, M.; Bhandari, B.; Wang, Y. 3D printing: Printing precision and application in food sector. Trends Food Sci. Technol. 2017, 69, 83-94. [CrossRef]

41. Baiano, A. 3D Printed Foods: A Comprehensive Review on Technologies, Nutritional Value, Safety, Consumer Attitude, Regulatory Framework, and Economic and Sustainability Issues. Food Rev. Int. 2020, 1-31. [CrossRef]

42. Zhu, S.; Stieger, M.A.; van der Goot, A.J.; Schutyser, M.A.I. Extrusion-based 3D printing of food pastes: Correlating rheological properties with printing behaviour. Innov. Food Sci. Emerg. Technol. 2019, 58, 102214. [CrossRef]

43. Liu, Z.; Chen, H.; Zheng, B.; Xie, F.; Chen, L. Understanding the structure and rheological properties of potato starch induced by hot-extrusion 3D printing. Food Hydrocoll. 2020, 105, 105812. [CrossRef]

44. Karavasili, C.; Gkaragkounis, A.; Moschakis, T.; Ritzoulis, C.; Fatouros, D.G. Pediatric-friendly chocolate-based dosage forms for the oral administration of both hydrophilic and lipophilic drugs fabricated with extrusion-based 3D printing. Eur. J. Pharm. Sci. 2020, 147, 105291. [CrossRef] [PubMed]

45. Kwak, C.; Young Ryu, S.; Park, H.; Lim, S.; Yang, J.; Kim, J.; Hyung Kim, J.; Lee, J. A pickering emulsion stabilized by chlorella microalgae as an eco-friendly extrusion-based 3D printing ink processable under ambient conditions. J. Colloid Interface Sci. 2021, 582, 81-89. [CrossRef] [PubMed]

46. Chen, H.; Xie, F.; Chen, L.; Zheng, B. Effect of rheological properties of potato, rice and corn starches on their hot-extrusion 3D printing behaviors. J. Food Eng. 2019, 244, 150-158. [CrossRef]

47. Sun, J.; Peng, Z.; Zhou, W.; Fuh, J.Y.H.; Hong, G.S.; Chiu, A. A Review on 3D Printing for Customized Food Fabrication. Procedia Manuf. 2015, 1, 308-319. [CrossRef]

48. Le-Bail, A.; Maniglia, B.C.; Le-Bail, P. Recent advances and future perspective in additive manufacturing of foods based on 3D printing. Curr. Opin. Food Sci. 2020, 35, 54-64. [CrossRef]

49. Kellens, K.; Mertens, R.; Paraskevas, D.; Dewulf, W.; Duflou, J.R. Environmental Impact of Additive Manufacturing Processes: Does AM Contribute to a More Sustainable Way of Part Manufacturing? Procedia CIRP 2017, 61, 582-587. [CrossRef]

50. Achillas, C.; Aidonis, D.; Iakovou, E.; Thymianidis, M.; Tzetzis, D. A methodological framework for the inclusion of modern additive manufacturing into the production portfolio of a focused factory. J. Manuf. Syst. 2015, 37, 328-339. [CrossRef] 
51. Peng, T.; Kellens, K.; Tang, R.; Chen, C.; Chen, G. Sustainability of additive manufacturing: An overview on its energy demand and environmental impact. Addit. Manuf. 2018, 21, 694-704. [CrossRef]

52. Upprinting Food-Sustainable 3D Food Printing. Available online:. Available online: https://www.upprintingfood.com/ (accessed on 15 December 2020).

53. Dilberoglu, U.M.; Gharehpapagh, B.; Yaman, U.; Dolen, M. The Role of Additive Manufacturing in the Era of Industry 4.0. Procedia Manuf. 2017, 11, 545-554. [CrossRef]

54. Davies, F.T.; Garrett, B. Technology for Sustainable Urban Food Ecosystems in the Developing World: Strengthening the Nexus of Food-Water-Energy-Nutrition. Front. Sustain. Food Syst. 2018, 2, 84. [CrossRef]

55. Wang, Y.; Ma, H.-S.; Yang, J.-H.; Wang, K.-S. Industry 4.0: A way from mass customization to mass personalization production. Adv. Manuf. 2017, 5, 311-320. [CrossRef]

56. Brettel, M.; Friederichsen, N.; Keller, M.; Rosenberg, M. How virtualization, decentralization and network building change the manufacturing landscape: An Industry 4.0 Perspective. Int. J. Mech. Ind. Sci. Eng. 2014, 8, 37-44.

57. De Mauro, A.; Greco, M.; Grimaldi, M. A formal definition of Big Data based on its essential features. Libr. Rev. 2016, 65, 122-135. [CrossRef]

58. Rezek Jambrak, A.; Vukusic, T.; Donsi, F.; Paniwnyk, L.; Djekic, I. Three Pillars of Novel Nonthermal Food Technologies: Food Safety, Quality, and Environment. J. Food Qual. 2018, 2018, 8619707. [CrossRef]

59. Castelo-Branco, I.; Cruz-Jesus, F.; Oliveira, T. Assessing Industry 4.0 readiness in manufacturing: Evidence for the European Union. Comput. Ind. 2019, 107, 22-32. [CrossRef]

60. Wang, S.; Wan, J.; Zhang, D.; Li, D.; Zhang, C. Towards smart factory for industry 4.0: A self-organized multi-agent system with big data based feedback and coordination. Comput. Netw. 2016, 101, 158-168. [CrossRef]

61. Djekic, I.; Mujčinović, A.; Nikolić, A.; Jambrak, A.R.; Papademas, P.; Feyissa, A.H.; Kansou, K.; Thomopoulos, R.; Breisen, H.; Kavallieratos, N.G.; et al. Cross-European initial survey on the use of mathematical models in food industry. J. Food Eng. 2019, 261, 109-116. [CrossRef]

62. Lucato, W.C.; Pacchini, A.P.T.; Facchini, F.; Mummolo, G. Model to evaluate the Industry 4.0 readiness degree in Industrial Companies. IFAC-PapersOnLine 2019, 52, 1808-1813. [CrossRef]

63. Aheleroff, S.; Xu, X.; Lu, Y.; Aristizabal, M.; Pablo Velásquez, J.; Joa, B.; Valencia, Y. IoT-enabled smart appliances under industry 4.0: A case study. Adv. Eng. Inform. 2020, 43, 101043. [CrossRef]

64. Yong, W.; Shuaishuai, L.; Li, L.; Minzan, L.; Ming, L.; Arvanitis, K.G.; Georgieva, C.; Sigrimis, N. Smart Sensors from Ground to Cloud and Web Intelligence. IFAC-PapersOnLine 2018, 51, 31-38. [CrossRef]

65. Oliveira, T.; Morais, S. New Generation of Electrochemical Sensors Based on Multi-Walled Carbon Nanotubes. Appl. Sci. 2018, 8 , 1925. [CrossRef]

66. Krzysztof ROMAN, K.; Borek, K.; Mazur, K.; Jan WARDAL, W. The measurements of PM 2.5 dust concentration by using an inte-grated optical sensor. Branch Warsaw 2020. [CrossRef]

67. Koyun, A.; Ahlatcolu, E.; Koca, Y. Biosensors and Their Principles. In A Roadmap of Biomedical Engineers and Milestones; InTech: London, UK, 2012.

68. Perumal, V.; Hashim, U. Advances in biosensors: Principle, architecture and applications. J. Appl. Biomed. 2014, 12, 1-15. [CrossRef]

69. Smart, A.; Crew, A.; Doran, O.; Hart, J.P. Studies Towards the Development of a Novel, Screen-Printed Carbon-Based, Biosensor for the Measurement of Polyunsaturated Fatty Acids. Appl. Sci. 2020, 10, 7779. [CrossRef]

70. Nikoleli, G.-P.; Siontorou, C.G.; Nikolelis, M.-T.; Bratakou, S.; Bendos, D.K. Recent Lipid Membrane-Based Biosensing Platforms. Appl. Sci. 2019, 9, 1745. [CrossRef]

71. Braik, M.; Barsan, M.M.; Dridi, C.; Ben Ali, M.; Brett, C.M.A. Highly sensitive amperometric enzyme biosensor for detection of superoxide based on conducting polymer/CNT modified electrodes and superoxide dismutase. Sens. Actuators B Chem. 2016, 236, 574-582. [CrossRef]

72. Maleki, N.; Kashanian, S.; Maleki, E.; Nazari, M. A novel enzyme based biosensor for catechol detection in water samples using artificial neural network. Biochem. Eng. J. 2017, 128, 1-11. [CrossRef]

73. Ye, Y.; Ji, J.; Sun, Z.; Shen, P.; Sun, X. Recent advances in electrochemical biosensors for antioxidant analysis in foodstuff. TrAC Trends Anal. Chem. 2020, 122, 115718. [CrossRef]

74. Rawal, R.; Chawla, S.; Pundir, C.S. Polyphenol biosensor based on laccase immobilized onto silver nanoparticles/multiwalled carbon nanotube/polyaniline gold electrode. Anal. Biochem. 2011, 419, 196-204. [CrossRef] [PubMed]

75. Ibarra-Escutia, P.; Gómez, J.J.; Calas-Blanchard, C.; Marty, J.L.; Ramírez-Silva, M.T. Amperometric biosensor based on a high resolution photopolymer deposited onto a screen-printed electrode for phenolic compounds monitoring in tea infusions. Talanta 2010, 81, 1636-1642. [CrossRef] [PubMed]

76. Gomes, S.A.S.S.; Nogueira, J.M.F.; Rebelo, M.J.F. An amperometric biosensor for polyphenolic compounds in red wine Biosens. Bioelectron. 2004, 20, 1211-1216. [CrossRef] [PubMed]

77. Mahbub, M. A smart farming concept based on smart embedded electronics, internet of things and wireless sensor network. Internet Things 2020, 9, 100161. [CrossRef]

78. Meier, J.; Mauser, W.; Hank, T.; Bach, H. Assessments on the impact of high-resolution-sensor pixel sizes for common agricultural policy and smart farming services in European regions. Comput. Electron. Agric. 2020, 169, 105205. [CrossRef] 
79. Bresnahan, P.J.; Wirth, T.; Martz, T.; Shipley, K.; Rowley, V.; Anderson, C.; Grimm, T. Equipping smart coasts with marine water quality IoT sensors. Results Eng. 2020, 5, 100087. [CrossRef]

80. Huang, X.; Li, Z.; Zou, X.; Shi, J.; Elrasheid Tahir, H.; Xu, Y.; Zhai, X.; Hu, X. A low cost smart system to analyze different types of edible Bird's nest adulteration based on colorimetric sensor array. J. Food Drug Anal. 2019, 27, 876-886. [CrossRef]

81. de Macêdo, I.Y.L.; Garcia, L.F.; Oliveira Neto, J.R.; de Siqueira Leite, K.C.; Ferreira, V.S.; Ghedini, P.C.; de Souza Gil, E. Electroanalytical tools for antioxidant evaluation of red fruits dry extracts. Food Chem. 2017, 217, 326-331. [CrossRef]

82. Beshai, H.; Sarabha, G.; Rathi, P.; Alam, A.; Deen, M. Freshness Monitoring of Packaged Vegetables. Appl. Sci. 2020, 10, 7937. [CrossRef]

83. Langmann, R.; Stiller, M. The PLC as a Smart Service in Industry 4.0 Production Systems. Appl. Sci. 2019, 9, 3815. [CrossRef]

84. Oztemel, E.; Gursev, S. Literature review of Industry 4.0 and related technologies. J. Intell. Manuf. 2020, 31, 127-182. [CrossRef]

85. Xu, L.D.; Xu, E.L.; Li, L. Industry 4.0: State of the art and future trends. Int. J. Prod. Res. 2018, 56, 2941-2962. [CrossRef]

86. Salah, B.; Abidi, M.H.; Mian, S.H.; Krid, M.; Alkhalefah, H.; Abdo, A. Virtual reality-based engineering education to enhance manufacturing sustainability in industry 4.0. Sustainability 2019, 11, 1477. [CrossRef]

87. Muller, J.M.; Kiel, D.; Voigt, K.I. What drives the implementation of Industry 4.0. The role of opportunities and challenges in the context of sustainability. Sustainability 2018, 10, 247.

88. Stock, T.; Seliger, G. Opportunities of sustainable manufacturing in industry 4.0. Procedia Cirp 2016, 40, 536-541. [CrossRef]

89. Miranda, J.; Ponce, P.; Molina, A.; Wright, P. Sensing, smart and sustainable technologies for Agri-Food 4.0. Comput. Ind. 2019, 108, 21-36. [CrossRef]

90. FAO. FAO and the 17 Sustainable Development Goals; The Food and Agriculture Organization of the United Nations: Rome, Italy, 2015.

91. Bai, C.; Dallasega, P.; Orzes, G.; Sarkis, J. Industry 4.0 technologies assessment: A sustainability perspective. Int. J. Prod. Econ. 2020, 229, 107776. [CrossRef]

92. Lu, Y. Industry 4.0: A survey on technologies, applications and open research issues. J. Ind. Inf. Integr. 2017, 6, 1-10. [CrossRef]

93. Djekic, I.; Tomasevic, I. Role of Sustainable Quality in the Food Chain. In Zero Hunger; Leal Filho, W., Azul, A.M., Brandli, L., Özuyar, P.G., Wall, T., Eds.; Springer International Publishing: Cham, Switzerland, 2020; pp. 1-10. ISBN 978-3-319-69626-3.

94. Djekic, I.; Tomasevic, I. Role of Potable Water in Food Processing. In Clean Water and Sanitation; Leal Filho, W., Azul, A.M., Brandli, L., Lange Salvia, A., Wall, T., Eds.; Springer International Publishing: Cham, Switzerland, 2020; pp. 1-10. ISBN 978-3-319-95845-3.

95. Djekic, I.; Petrovic, J.; Božičković, A.; Djordjevic, V.; Tomasevic, I. Main environmental impacts associated with production and consumption of milk and yogurt in Serbia-Monte Carlo approach. Sci. Total Environ. 2019, 695, 133917. [CrossRef]

96. Griggs, D.; Stafford-Smith, M.; Gaffney, O.; Rockström, J.; Öhman, M.C.; Shyamsundar, P.; Steffen, W.; Glaser, G.; Kanie, N.; Noble, I. Sustainable development goals for people and planet. Nature 2013, 495, 305-307. [CrossRef] [PubMed]

97. Morrar, R.; Arman, H.; Mousa, S. The fourth industrial revolution (Industry 4.0): A social innovation perspective. Technol. Innov. Manag. Rev. 2017, 7, 12-20. [CrossRef]

98. Dalenogare, L.S.; Benitez, G.B.; Ayala, N.F.; Frank, A.G. The expected contribution of Industry 4.0 technologies for industrial performance. Int. J. Prod. Econ. 2018, 204, 383-394. [CrossRef]

99. Rüßmann, M.; Lorenz, M.; Gerbert, P.; Waldner, M.; Justus, J.; Engel, P.; Harnisch, M. Industry 4.0: The future of productivity and growth in manufacturing industries. Bost. Consult. Gr. 2015, 9, 54-89.

100. Hospido, A.; Davis, J.; Berlin, J.; Sonesson, U. A review of methodological issues affecting LCA of novel food products. Int. J. Life Cycle Assess. 2010, 15, 44-52. [CrossRef]

101. Wernet, G.; Bauer, C.; Steubing, B.; Reinhard, J.; Moreno-Ruiz, E.; Weidema, B. The ecoinvent database version 3 (part I): Overview and methodology. Int. J. Life Cycle Assess. 2016, 21, 1218-1230. [CrossRef]

102. Solangi, Y.A.; Tan, Q.; Mirjat, N.H.; Ali, S. Evaluating the strategies for sustainable energy planning in Pakistan: An integrated SWOT-AHP and Fuzzy-TOPSIS approach. J. Clean. Prod. 2019, 236, 117655. [CrossRef]

103. Sharma, L.; Pandey, S. Recovery of resources from end-of-life passenger cars in the informal sector in India. Sustain. Prod. Consum. 2020, 24, 1-11. [CrossRef]

104. Nara, E.O.B.; da Costa, M.B.; Baierle, I.C.; Schaefer, J.L.; Benitez, G.B.; do Santos, L.M.A.L.; Benitez, L.B. Expected impact of industry 4.0 technologies on sustainable development: A study in the context of Brazil's plastic industry. Sustain. Prod. Consum. 2021, 25, 102-122. [CrossRef]

105. Dantas, T.E.T.; de-Souza, E.D.; Destro, I.R.; Hammes, G.; Rodriguez, C.M.T.; Soares, S.R. How the combination of Circular Economy and Industry 4.0 can contribute towards achieving the Sustainable Development Goals. Sustain. Prod. Consum. 2021, 26, 213-227. [CrossRef] 